\title{
Kontribusi Pembiayaan Bank Syariah untuk Sektor Pertanian di Indonesia
}

Contribution of Islamic Bank Financing for Agricultural Sector in Indonesia

\author{
Minhatul Mughits ${ }^{1}$, Ries Wulandari ${ }^{2}$ \\ ${ }^{1}$ Program Studi Ilmu Ekonomi Islam, Sekolah Tinggi Ekonomi Islam Tazkia \\ ${ }^{2}$ Program Studi Ilmu Ekonomi Islam, Sekolah Tinggi Ekonomi Islam Tazkia
}

\begin{abstract}
Based on Islamic Banking Law Article 1 paragraph 2 funding was the main activity for Islamic banking in its function as a financial intermediary and drived real sector. This study was aim to determine how much the influences of SBIS, amount of DPK, Non Performing Financing and the exchange rate of dollar against the Islamic banking financing as well as the contribution of Islamic bank financing for the agricultural sector in Indonesia by using VAR/VECM approach. VECM results indicated variables that affected agricultural financing in the short term was variable LNER and SBIS. While in the long term variable $\operatorname{lnDPK}$ and $\operatorname{lnNPF}$ statistically significant against to agricultural financing. The results of IRF showed that $\operatorname{lnDPK}, \operatorname{lnNPF}$ and LNER responded positively influencing the contribution of financing on Islamic bank for the agricultural sector in Indonesia. As for The contribution of financing on Islamic bank for the agricultural sector in Indonesia, LNER gave the largest contribution to the Islamic bank financing for the agricultural sector in Indonesia, followed by the variable SBIS, InDPK, and lnNPF. The higher value of rupiah would increase the financing by the islamic banking for Agricultural sector, as would as the lower of rate SBIS would increase the financing of islamic banking.
\end{abstract}

Keywords: Financing, Islamic Bank, VAR/VECM

\section{Pendahuluan}

Indonesia adalah negara agraris, dikarenakan kondisi alam dan geografis negara Indonesia yang terdiri dari berbagai pulau serta sebagian penduduk Indonesia bermata pencaharian sebagai petani. Hal tersebut menjadi salah satu penyebab sektor pertanian di Indonesia memiliki peran penting dalam pembangunan nasional. Tidak hanya sebagai sumber mata pencaharian, sektor pertanian di Indonesia juga memberikan kontribusi yang cenderung positif terhadap PDB. Hal tersebut dapat dilihat dari Data Badan Pusat Statistik (BPS) tentang peran Sektor Pertanian terhadap Produk Domestik Bruto (PDB) dari tahun 2011 sampai dengan 2013 yang menunjukkan peningkatan yang cukup besar yakni mencapai nilai Rp 216.872,5 Miliar.

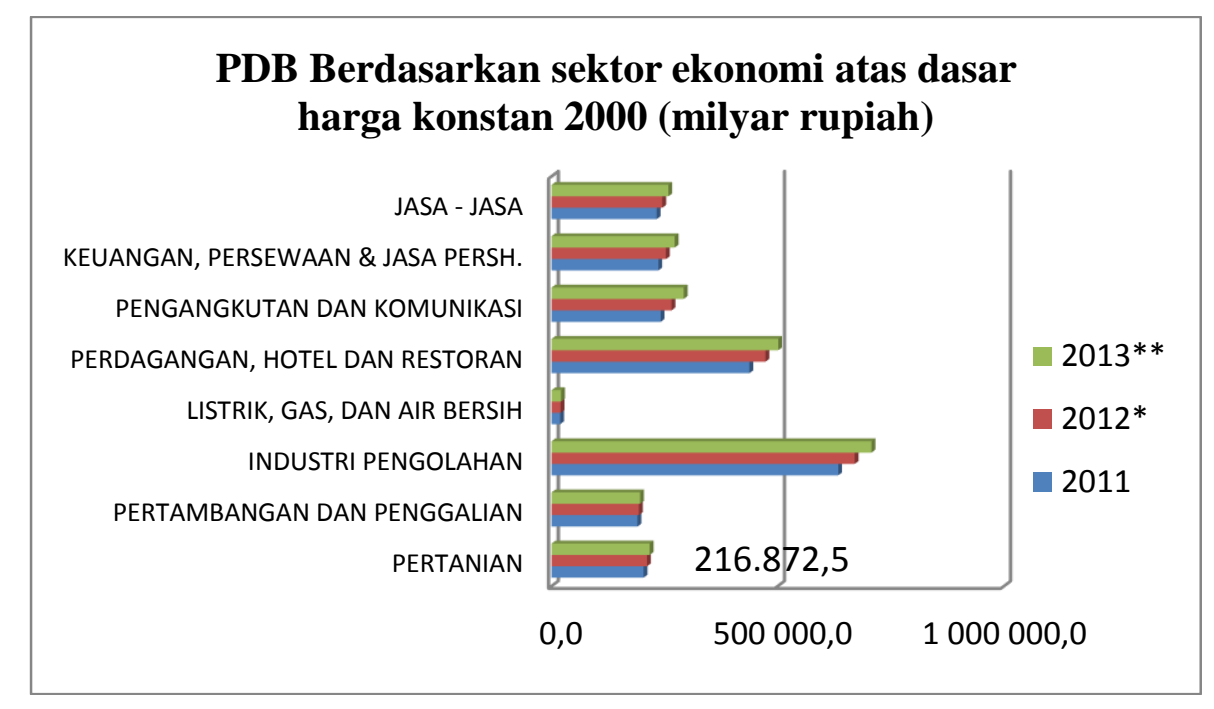

Gambar 1 PDB berdasarkan sektor ekonomi atas dasar harga konstan 
Selain memberikan peran terhadap PDB, Sektor Pertanian juga memberikan dampak yang cukup signifikan terhadap sektor tenaga kerja. Data BPS menunjukkan bahwa pada tahun 2014 terdapat total 79.806.085 jiwa bekerja pada sektor pertanian. Akan tetapi, sektor pertanian bukannya lepas dari permasalahan. Diantara permasalahan yang menjadi kendala bagi sektor pertanian adalah semakin banyaknya konversi pertanian yang dikarenakan oleh kurangnya modal petani untuk menjalankan kegiatan pertanian. (Yasin, 2015). Selain itu, terdapat juga faktor cuaca yang menyebabkan kegagalan panen sehingga menurunkan hasil pengolahan pertanian. Pada bulan juli tahun 2015, terdapat total 5.929 ha sawah kekeringan, dan total 34.222 ha sawah gagal panen karena banjir yang tersebar di seluruh wilayah Indonesia. (Kementrian Pertanian, 2015).

Tabel 1 Kegagalan Panen Berdasarkan Faktor Penyebab dan Wilayah

\begin{tabular}{ccccc}
\hline PUSO & $\begin{array}{c}\text { Musim } \\
\text { Hujan }\end{array}$ & Wilayah & $\begin{array}{c}\text { Musim } \\
\text { Kemarau }\end{array}$ & Wilayah \\
\hline Kekeringan & 5.929 ha & $\begin{array}{c}\text { Provinsi Sulawesi } \\
\text { Tengah, Sulawesi } \\
\text { Selatan dan Jawa Tengah }\end{array}$ & 10.696 ha & $\begin{array}{c}\text { Provinsi Jawa Tengah, } \\
\text { Jawa Timur dan Jawa } \\
\text { Barat }\end{array}$ \\
\hline OPT & 476 ha & $\begin{array}{c}\text { Provinsi Jawa Tengah, } \\
\text { Banten dan Sulawesi } \\
\text { Tenggara }\end{array}$ & 5.320 ha & $\begin{array}{c}\text { Provinsi Sumatera } \\
\text { Selatan, Jawa Timur } \\
\text { dan Sulawesi Tenggara }\end{array}$ \\
\hline Banjir & 34.222 ha & $\begin{array}{c}\text { Provinsi Aceh, Jawa } \\
\text { Timur dan Banten }\end{array}$ & 3.708 ha & $\begin{array}{c}\text { Provinsi Sulawesi } \\
\text { Selatan, Jawa Tengah } \\
\text { dan Jawa Timur }\end{array}$ \\
\hline
\end{tabular}

Kurangnya pembiayaan sektor pertanian yang kemudian menyebabkan menurunnya hasil pertanian, dan pada jangka panjang mengurangi peran sektor pertanian terhadap PDB adalah hal yang sangat disayangkan, mengingat besarnya potensi sektor pertnian bagi pembangunan Indonesia. Salah satu masalah kurangnya pembiayaan sektor pertanian oleh sektor keuangan adalah anggapan bahwa sektor pertanian merupakan sektor usaha yang memiliki resiko sangat tinggi dibandingkan dengan sektor usaha yang lainnya. (Thoha \& Saptia, 2009).

Tabel 2 Alokasi Pembiayaan Dana Perbankan Kredit Pertanian (Milyar Rupiah)

\begin{tabular}{ccccc}
\hline SEKTOR EKONOMI & $\mathbf{2 0 1 1}$ & $\mathbf{2 0 1 2}$ & $\mathbf{2 0 1 3}$ & $\mathbf{2 0 1 4}$ \\
\hline $\begin{array}{c}\text { Pertanian, kehutanan dan sarana } \\
\text { pertanian }\end{array}$ & 2.201 & 2.809 & 38.326 & 50.500 \\
\hline Pertambangan & 1.733 & 2.094 & 33.622 & 42.689 \\
\hline Perindustrian & 4.077 & 5.008 & 67.951 & 111.351 \\
\hline Listrik, gas dan air & 2.381 & 3.159 & 47.981 & 49.740 \\
\hline Konstruksi & 5.858 & 7.142 & 92.164 & 106.200 \\
\hline Perdagangan, restoran dan hotel & 9.778 & 12.624 & 164.078 & 216.252 \\
\hline $\begin{array}{c}\text { Pengangkutan, pergudangan dan } \\
\text { komunikasi }\end{array}$ & 3.369 & 4.321 & 64.273 & 121.292 \\
\hline Jasa dunia usaha & 25.630 & 37.150 & 504.976 & 660.324 \\
\hline Jasa sosial/masyarakat & 4.464 & 7.878 & 114.792 & 120.064 \\
\hline Lain-lain & 43.164 & 65.319 & 909.137 & 619.923 \\
\hline
\end{tabular}

Minimnya alokasi kredit di sektor pertanian dapat dipecahkan salah satunya dengan alternatif pembiayaan yang dikembangkan dengan pola syariah pada bank syariah. Pola pembiyaan dengan prinsip syariah mulai berkembang sejak berdirinya Bank Muamalat tahun 1992, dan kemudian diterbitkannya Undang-undang No.10 tahun 1998 tentang perubahan UU No.7 tahun 1992 tentang 
perbankan yang memberikan landasan hukum yang lebih kuat bagi keberadaan sistem perbankan syariah di Indonesia.

Pola syariah bisa menjadi alternatif pembiayaan untuk sektor pertanian khususnya yang terpenting terhindar dari riba, dengan kata lain tidak ada tambahan yang diambil dari pengembalian yang diambil oleh perbankan diluar perjanjian dan pokok dana. Selain itu, pola syariah cenderung tidak berpihak pada salah satu pembiayaan baik perbankan maupun nasabah, melainkan memberikan kemaslahatan bersama yakni dengan keuntungan maupun kerugian ditanggung bersama (sistem bagi hasil). Ditambahkan dengan sektor pertanian yang terbilang cukup memegang resiko yang besar akibat waktu panen yang terbilang rentan terhadap iklim yang ada, menjadikan pola syariah mampu menjadi alternatif pembiayaan untuk sektor pertanian di Indonesia dengan sistem bagi hasil yang diterapkan oleh perbankan syariah.

Dari berbagai sumber data dan hasil penelitian yang dilakukan, garis besar permasalahan yang dihadapi sektor pertanian di Indonesia yakni: regulasi yang terbatas (Nurmanaf, 2007), minimnya sarana informasi mengenai pembiayaan sektor pertanian (Arifin, 2007), beresiko tinggi (Hastuti \& Supadi, T,th) dan berbagai permasalahan lainnya. Oleh karena itu, berdasarkan pada latar belakang diatas, peneliti tertarik untuk mengangkat masalah ini dalam sebuah penelitian dengan judul “Kontribusi Pembiayaan Perbankan Syariah Untuk Sektor Pertanian di Indonesia”. Sehingga kontribusi pembiayaan bank syariah untuk sektor pertanian diharapkan mampu memberikan peningkatan.

Sehingga tujuan penelitian kali ini adalah untuk mengetahui faktor apa saja yang mampu mempengaruhi kontribusi pembiayaan yang disalurkan perbankan syariah untuk sektor pertanian di Indonesia. Kemudian untuk mengetahui respon yang diterima pembiayaan bank syariah untuk sektor pertanian di Indonesia terhadap shock yang terjadi pada masing-masing variabel dalam jangka panjang melalui hasil analisis Impulse Response Function (IRF). Serta untuk mengetahui kontribusi pengaruh masing-masing variabel terhadap pembiayaan bank syariah untuk sektor pertanian di Indonesia melalui hasil analisis Forecast Error Variance Decomposition (FEVD).

Sedangkan penelitian terdahulu yang berkaitan dengan penelitian kali ini adalah Pratama (2010), Astuti (2009), Maula (2008), Veratama (2013), Arianti dan Muharam (2011), Rimadhani dan Ezra (2011), Abdussalam (2009), Saptia (2009), Firmansyah (2009), Faisal (2013), Beik dan Aprianti (2013), Pasaribu,et.al (2007), Mançka (2012), dan Nurmanaf, et.al (2006).

\section{Metode Penelitian}

Penelitian ini menggunakan data sekunder. Data sekunder yang digunakan adalah data deret waktu (time-series) bulanan selama bulan Januari tahun 2009 - Desember 2014. Data diperoleh dari website resmi Bank Indonesia yaitu Statistik Perbankan Indonesia dan Statistik Perbankan Syariah dan Badan Pusat Statistik (BPS) dan Otoritas Jasa Keuangan (OJK). Data yang digunakan adalah jumlah dana pihak ketiga (lnDPK), Non Performing Financing (lnNPF), nilai tukar rupiah terhadap dolar amerika (lnER) dan Imbalan Sertifikan Bank Indonesia Syariah (SBIS) terhadap Pembiayaan pertanian (lnPP). 


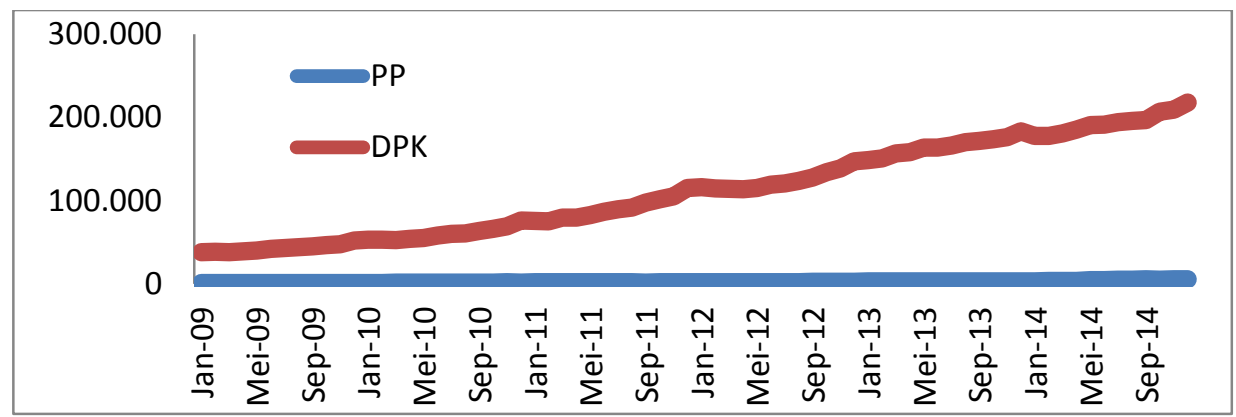

Gambar 2 Pembiayaan yang disalurkan untuk pertanian dan Dana Pihak Ketiga Perbankan Syariah

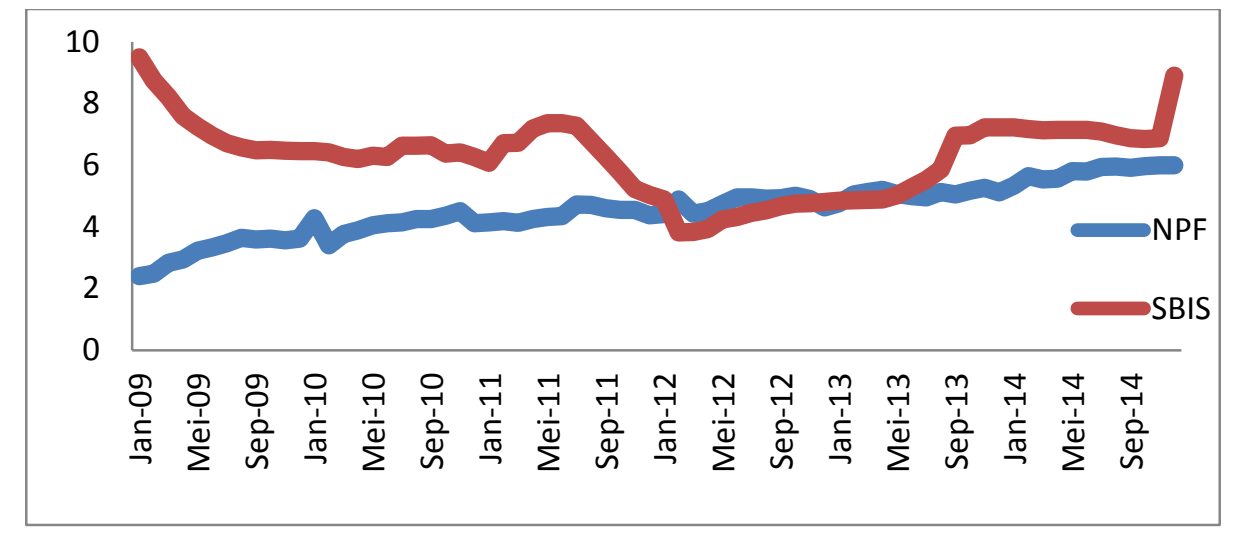

Gambar 3 Non Performing Financing dan Imbalan SBIS Perbankan Syariah

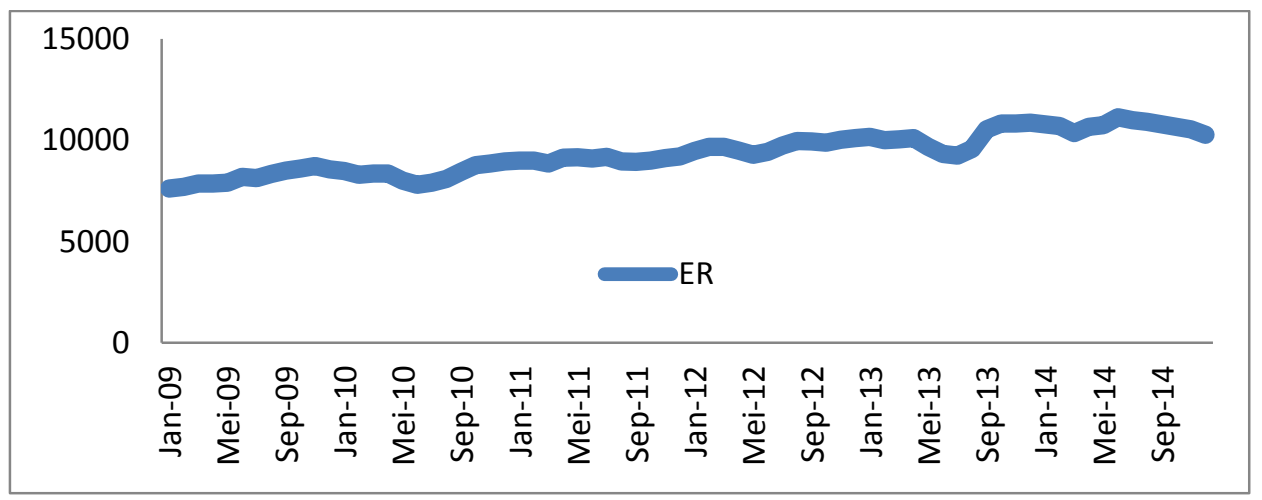

Gambar 4 Nilai Tukar Rupiah Terhadap Dollar

Untuk menjawab tujuan penelitian, Metode penelitian yang digunakan adalah VAR-VECM. Dimana metode ini mengasumsikan bahwa seluruh variabel dalam persamaan simultan adalah variabel endogen. (Ascarya, 2010). Model penelitian VAR-VECM juga tidak dibangun di atas teori. Hal ini dikarenakan dalam kenyataannya banyak teori yang memberikan penjelasan berbeda terhadap suatu fenomena. (Nachrowi, 2006).

Menurut Enders (2004), secara umum model VAR dapat kita tulis sebagai berikut:

$$
Y_{t}=A_{0}+A_{1} Y_{t-1}+A_{2} Y_{t-1}+\ldots .+A_{p} Y_{t-p}+\varepsilon_{t}
$$

Dimana:

$P \quad=$ Jumlah variabel dalam sistem persamaan

$A o=$ Vektor $(\mathrm{nx} 1)$ yang berisi $\mathrm{n}$ dari masing-masing variabel dama VAR

$A i=$ Matriks-matriks koefisien berdimensi ( $\mathrm{n} \times \mathrm{n}$ )

$\varepsilon_{t}=$ Vektor $(\mathrm{nx} 1)$ dari error term

Jurnal Al-Muzara'ah Vol.4, No.1, 2016 
Dalam analisis VAR, data yang dipakai harus bersifat stasioner atau tidak mengandung unit root pada level. Namun pada kenyataannya, data time series pada umumnya tidak stasioner pada level, dan baru stasioner pada first difference. Hal ini menyebabkan informasi jangka panjang menjadi hilang. Untuk mengantisipasi hilangnya informasi jangka panjang tersebut, dapat digunakan model VECM. Hal ini dilakukan bila terdapat minimal satu persamaan yang terkointegrasi.

Adapun model VECM dapat ditulis secara matematis sebagai berikut:

$$
\Delta Y_{t}=\Sigma_{i-1}^{k-1} \Gamma_{i} \Delta Y_{t-1}-\gamma \beta Y_{t-1}+\varepsilon_{t}
$$

Dimana:

$\Gamma=$ Koefisien hubungan jangka pendek

$\beta=$ Koefisien hubungan jangka panjang

$\gamma=$ Koefisien hubungan menuju keseimbangan (speed adjustment)

Langkah-langkah pengujian VAR-VECM dibagi kedalam pengujian Stasioneritas Data, apabila data stasioner pada level, maka dilakukan pengujian VAR, dan apabila data stasioner pada first difference maka terdapat dua pilihan pengujian, yakni VAR dalam bentuk first difference atau VECM (Arsana, 2004). Kemudian stabilitas Model VAR, Uji Optimum Lag, Uji Hubungan Kointegrasi, dan analisis Impulse Response Function (IRF) dan analisis Forecast Error Variance Decomposition (FEVD). Secara sederhana, langkah pengujian VAR-VECM digambarkan sebagai berikut:

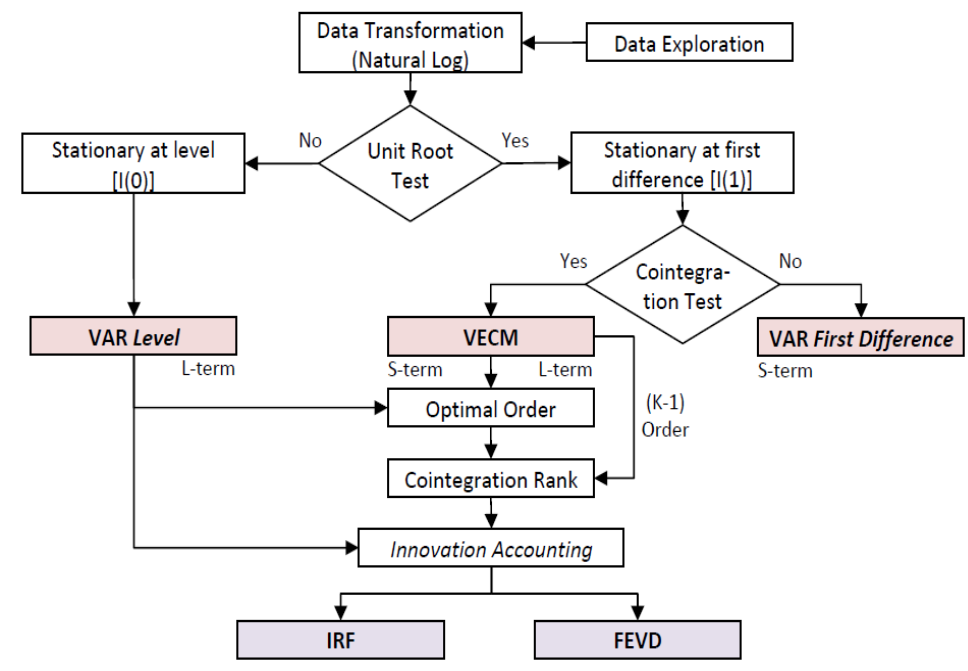

Gambar 5 Langkah Pengujuan VAR-VECM

Sumber: Ascarya, 2009.

Sedangkan model penelitian VAR-VECM kali ini adalah sebagai berikut:

Model VAR untuk penelitian ini adalah:

$$
\left[\begin{array}{c}
\ln P P_{\mathrm{t}} \\
\ln D P K_{\mathrm{t}} \\
\ln N P F_{\mathrm{t}} \\
\ln E R_{\mathrm{t}} \\
\mathrm{SBIS}_{\mathrm{t}}
\end{array}\right]=\left[\begin{array}{l}
\beta_{10} \\
\beta_{20} \\
\beta_{30} \\
\beta_{40} \\
\beta_{50}
\end{array}\right]+\left[\begin{array}{lllll}
\beta_{11} & \beta_{12} & \beta_{13} & \beta_{14} & \beta_{15} \\
\beta_{21} & \beta_{22} & \beta_{23} & \beta_{24} & \beta_{25} \\
\beta_{31} & \beta_{32} & \beta_{33} & \beta_{34} & \beta_{35} \\
\beta_{41} & \beta_{42} & \beta_{43} & \beta_{44} & \beta_{45} \\
\beta_{51} & \beta_{52} & \beta_{53} & \beta_{54} & \beta_{55}
\end{array}\right]\left[\begin{array}{c}
\ln P P_{\mathrm{t}-1} \\
\ln D P K_{\mathrm{t}-1} \\
\ln N P F_{\mathrm{t}-1} \\
\ln E R_{\mathrm{t}-1} \\
\mathrm{SBIS} \mathrm{t}_{\mathrm{t}-1}
\end{array}\right]+\left[\begin{array}{l}
\mu_{1 \mathrm{t}} \\
\mu_{2 \mathrm{t}} \\
\mu_{3 \mathrm{t}} \\
\mu_{4 \mathrm{t}} \\
\mu_{5 \mathrm{t}}
\end{array}\right]
$$

Sedangkan untuk persamaan VECM dalam model persamaan variabel penelitian sebagai berikut: 


$$
\left[\begin{array}{c}
\Delta \ln P F_{\mathrm{t}} \\
\Delta \ln D P K_{\mathrm{t}} \\
\Delta \ln N P F_{\mathrm{t}} \\
\Delta \ln E R_{\mathrm{t}} \\
\Delta \mathrm{SBIS}
\end{array}\right]=\left[\begin{array}{l}
\beta_{10} \\
\beta_{20} \\
\beta_{30} \\
\beta_{40} \\
\beta_{50}
\end{array}\right]+\left[\begin{array}{lllll}
\beta_{11} & \beta_{12} & \beta_{13} & \beta_{14} & \beta_{15} \\
\beta_{21} & \beta_{22} & \beta_{23} & \beta_{24} & \beta_{25} \\
\beta_{31} & \beta_{32} & \beta_{33} & \beta_{34} & \beta_{35} \\
\beta_{41} & \beta_{42} & \beta_{43} & \beta_{44} & \beta_{45} \\
\beta_{51} & \beta_{52} & \beta_{53} & \beta_{54} & \beta_{55}
\end{array}\right]\left[\begin{array}{c}
\Delta \ln P P_{\mathrm{t}-1} \\
\Delta \ln D P K_{\mathrm{t}-1} \\
\Delta \ln N P F_{\mathrm{t}-1} \\
\Delta \ln E R_{\mathrm{t}-1} \\
\Delta \mathrm{SBIS} \mathrm{t}_{\mathrm{t}-1}
\end{array}\right]-\lambda\left[\begin{array}{l}
\varepsilon_{1 \mathrm{t}} \\
\varepsilon_{2 \mathrm{t}} \\
\varepsilon_{3 \mathrm{t}} \\
\varepsilon_{4 \mathrm{t}} \\
\varepsilon_{5 \mathrm{t}}
\end{array}\right]
$$

\section{Hasil dan Pembahasan}

\section{Uji Stasioneritas Data}

Metode pengujian yang diaplikasikan dalam tahap pertama uji penelitian ini (unit root test) adalah uji Augmented Dickey-Fuller (ADF) dengan menggunakan taraf nyata sebesar lima persen dan data dalam model penelitian ini sudah stasioner dikarenakan tidak mengandung akar unit. Berikut hasil uji unit root dapat dilihat pada Tabel berikut:

\section{Tabel 3 Hasil Uji Stasioneritas}

\begin{tabular}{ccccc}
\hline \multirow{2}{*}{ variabel } & \multicolumn{2}{c}{ ADF Value } & \multicolumn{2}{c}{ ADF Value } \\
\cline { 2 - 5 } & Level & Prob & First & Prob \\
\hline Lnpp & 1.031054 & 0.9966 & $\mathbf{- 1 0 . 9 4 2 7 8}$ & 0.0001 \\
Lndpk & -1.405234 & 0.5751 & $\mathbf{- 7 . 7 4 6 8 2 0}$ & 0.0000 \\
Lnnpf & -1.780264 & 0.3872 & $\mathbf{- 8 . 3 9 3 5 9 0}$ & 0.0000 \\
Lner & -1.867626 & 0.3455 & $\mathbf{- 5 . 6 0 4 3 7 1}$ & 0.0000 \\
Sbis & -1.111181 & 0.7071 & $\mathbf{- 3 . 7 6 2 8 8 0}$ & 0.0051 \\
\hline
\end{tabular}

Catatan : cetak tebal menunjukkan bahwa data stasioner pada nilai kritis McKinnon sebesar $5 \%$

Berdasarkan hasil uji unit root dapat dilihat bahwa seluruh variabel penelitian yakni $\ln P P$, $\operatorname{lnDPK}$, lnNPF, lnER dan SBIS stasioner pada tingkat first difference. Apabila data yang diuji stasioner pada tingkat level, maka metode yang digunakan adalah VAR, sedangkan jika data yang diuji tidak stasioner pada tingkat level namun stasioner pada tingkat first difference maka metode yang digunakan adalah VECM. Model VAR yang digunakan dalam penelitian akan dikombinasikan dengan model VECM hanya jika terdapat minimal satu kointegrasi dalam model.

\section{Hasil Uji Korelasi}

Untuk mengetahui hubungan antar variabel yang digunakan dalam penelitian, maka perlu dilakukan pengujian korelasi antar variabel guna mengetahui bentuk urutan variabel yang sesuai. Adapun hasil uji korelasi dapat dilihat dalam Tabel berikut:

Tabel 4 Hasil Uji Korelasi

\begin{tabular}{c|c|c|c|c|c}
\hline & Lnpp & Indpk & Innpf & Iner & Sbis \\
\hline Lnpp & 1.000 .000 & $\mathbf{0 . 9 4 8 9 6 4}$ & $\mathbf{0 . 9 4 1 2 9 5}$ & $\mathbf{0 . 9 0 6 9 0 0}$ & -0.061914 \\
\hline Lndpk & $\mathbf{0 . 9 4 8 9 6 4}$ & 1.000 .000 & $\mathbf{0 . 9 4 3 1 4 7}$ & $\mathbf{0 . 9 4 1 3 9 0}$ & $\mathbf{- 0 . 2 6 1 8 0 5}$ \\
\hline Lnnpf & $\mathbf{0 . 9 4 1 2 9 5}$ & $\mathbf{0 . 9 4 3 1 4 7}$ & 1.000 .000 & $\mathbf{0 . 9 0 5 7 6 4}$ & $\mathbf{- 0 . 2 1 0 9 0 9}$ \\
\hline Lner & $\mathbf{0 . 9 0 6 9 0 0}$ & $\mathbf{0 . 9 4 1 3 9 0}$ & $\mathbf{0 . 9 0 5 7 6 4}$ & 1.000 .000 & -0.194638 \\
\hline Sbis & -0.061914 & $\mathbf{- 0 . 2 6 1 8 0 5}$ & $\mathbf{- 0 . 2 1 0 9 0 9}$ & -0.194638 & 1.000 .000 \\
\hline
\end{tabular}

Berdasarkan hasil pada Tabel diatas, didapatkan urutan untul model pembiayaan sektor pertanian (lnPP) di Indonesia yaitu: $\operatorname{lnDPK}$, lnNPF, lnER dan SBIS. Urutan ini didapatkan dikarenakan jenis 
penelitian ini cenderung a-teori, maka pengurutan variabel dilakukan berdasarkan bilai korelasi terbesar hingga nilai korelasi terkecil.

\section{Hasil uji Stabilitas Model VAR}

Setelah dilakukan pengujian unit root, langkah selanjutnya dilakukan uji stabilitas model VAR. Model VAR dapat dikatakan stabil jika nilai modulus yang paling besar nilainya kurang dari satu dan berada pada titik optimal, dengan demikian dapat dikatakan model tersebut sudah berada pada posisi optimal dan model VAR sudah stabil.

Tabel 5 Hasil Uji Stabilitas Model VAR

\begin{tabular}{l|l|l}
\hline Persamaan & Maksimum Lag & Kisaran Modulus \\
\hline LNPP & 8 & $0.008752-0.992484$ \\
\hline
\end{tabular}

Berdasarkan hasil uji stabilitas model VAR dalam Tabel diatas dalam kisaran 0.008752 - 0.992484 dapat disimpulkan bahwa estimasi VAR yang digunakan untuk analisis IRF dan FEVD sudah stabil.

\section{Hasil Uji Lag Optimum}

Uji lag optimum dilakukan dengan tujuan untuk menghilangkan masalah autokorelasi dalam sistem VAR. Sehingga dengan digunakannya lag optimum diharapkan tidak muncul lagi masalah autokorelasi. Penentuan lag optimum ditentukan berdasarkan beberapa informasi seperti kriteria Likelihood Ratio (LR), Final Prediction Error (FPE), Akaike Information Criterion (AIC), Schwartz Criterion (SC) ataupun Hanna-Quin Criterion (HQ) (Arsana, 2004).

Tabel 6 Hasil Uji Lag Optimum

\begin{tabular}{cccllll}
\hline \hline Lag & LogL & LR & FPE & AIC & SC & HQ \\
\hline \hline 0 & 392.6935 & NA & $5.44 \mathrm{e}-12$ & -11.74829 & $-11.58241^{*}$ & $-11.68274^{*}$ \\
1 & 417.8559 & $45.74980^{*}$ & $5.42 \mathrm{e}-12^{*}$ & $-11.75321^{*}$ & -10.75791 & -11.35992 \\
2 & 436.2925 & 30.72765 & $6.71 \mathrm{e}-12$ & -11.55432 & -9.729606 & -10.83329 \\
3 & 447.9506 & 17.66370 & $1.04 \mathrm{e}-11$ & -11.15002 & -8.495890 & -10.10125 \\
4 & 470.3654 & 30.56574 & $1.20 \mathrm{e}-11$ & -11.07168 & -7.588138 & -9.695167 \\
5 & 491.1963 & 25.24959 & $1.52 \mathrm{e}-11$ & -10.94534 & -6.632387 & -9.241090 \\
\hline \hline
\end{tabular}

Catatan: Tanda asetrik $(*)$ menunjukkan lag optimum berdasarkan kriteria.

Pada Tabel diatas dapat dilihat hasil uji lag optimum menyatakan bahwasannya lag optimal dalam penelitian ini berada pada lag 1 dengan kriteria Akaike Information Criteria (AIC).

\section{Hasil Uji Kointegrasi}

Uji kointegrasi dilakukan apabila data telah stasioner pada tingkat first difference untuk melihat kemungkinan terjadinya kointegrasi antar variabel. Dalam proses pengujiannya, data yang digunakan dirubah terlebih dahulu ke dalam data level (Ascarya, 2009). Uji kointegrasi merupakan salah satu cara yang digunakan untuk mengetahui apakah terdapat hubungan jangka panjang dan keseimbangan antar variabel yang stasioner pada tingkat first difference (Gujarati \& Porter, 2009). Penentuan banyaknya hubungan kointegrasi antar variabel dapat diketahui sesuai dengan metode trace yang dapat di lihat dari nilai trace statistic. Nilai trace statistic yang melebihi nilai kritisnya mengindikasikan bahwa terdapat kointegrasi dalam model yang digunakan. Untuk hasil uji kointegrasi dalam model persamaan pembiayaan untuk sektor pertanian dapat dilihat pada tabel berikut:

\section{Tabel 7 Hasil Uji Kointegrasi \\ Unrestricted Cointegration Rank Test (Trace)}




\begin{tabular}{lllll}
\hline \hline $\begin{array}{l}\text { Hypothesized } \\
\text { No. of CE(s) }\end{array}$ & Eigenvalue & $\begin{array}{l}\text { Trace } \\
\text { Statistic }\end{array}$ & $\begin{array}{l}0.05 \\
\text { Critical Value }\end{array}$ & Prob.** \\
\hline \hline None * & 0.330842 & 70.34275 & 69.81889 & 0.0454 \\
At most 1 & 0.279330 & 42.22127 & 47.85613 & 0.1526 \\
At most 2 & 0.131392 & 19.29107 & 29.79707 & 0.4721 \\
At most 3 & 0.114197 & 9.430658 & 15.49471 & 0.3270 \\
At most 4 & 0.013373 & 0.942411 & 3.841466 & 0.3317 \\
\hline \hline
\end{tabular}

Catatan: Tanda asetri $(*)$ terdapat persamaan yang terkointegrasi pada level $5 \%$

Berdasarkan hasil uji kointegrasi pada Tabel diatas dapat dilihat bahwa terdapat satu kointegrasi dalam model persamaan pembiayaan bank syariah untuk sektor pertanian di Indonesia. Dengan demikian penelitian selanjutnya dengan menggunakan model VECM dapat dilakukan, hal ini menunjukkan selain terdapat hubungan jangka pendek, terdapat pula hubungan jangka panjang antar variabel pada model penelitian.

\section{Analisis Uji VECM}

Tabel 8 Hasil Uji VECM pada Jangka Pendek dan Jangka Panjang

\begin{tabular}{|c|c|c|}
\hline \multicolumn{3}{|l|}{ Jangka Pendek } \\
\hline Variabel & Koefisien & T- Statistik \\
\hline CointEq1 & -0.021945 & {$[-1.27031]$} \\
\hline $\mathrm{D}(\mathrm{LNPP}(-1))$ & -0.206305 & {$[-1.74246]$} \\
\hline D(LNDPK(-1)) & 0.098058 & {$[0.76618]$} \\
\hline D(LNNPF(-1)) & -0.183941 & {$[-1.53260]$} \\
\hline $\mathrm{D}(\operatorname{LNER}(-1))$ & 0.362579 & [3.18165]* \\
\hline $\mathrm{D}(\mathrm{SBIS}(-1))$ & 0.467540 & [3.12998]* \\
\hline \multicolumn{3}{|l|}{ Jangka Panjang } \\
\hline LNDPK(-1) & -1.545947 & {$[2.95513]^{*}$} \\
\hline LNNPF(-1) & 1.409306 & {$[-5.10190]^{*}$} \\
\hline $\operatorname{LNER}(-1)$ & 2.687791 & {$[-1.30630]$} \\
\hline $\operatorname{SBIS}(-1)$ & -0.087988 & [ 1.37194$]$ \\
\hline $\mathrm{C}$ & 22.53849 & - \\
\hline
\end{tabular}

Catatan: Tanda asterik (*) menunjukkan signifikan terhadap alpha 5\%

Pada Tabel diatas, dapat diketahui hasil Uji VECM pada jangka pendek dan jangka panjang. Pada jangka pendek, hasil VECM menunjukkan bahwa terdapat koreksi kesalahan sebesar 0.021945 yang secara statistik tidak signifikan. Koreksi kesalahan berarti ketidakseimbangan akan dikoreksi sebesar 2,1945 persen untuk kembali pada keseimbangan jangka panjang di bulan berikutnya.

Pada jangka pendek, variabel yang mempengaruhi kontribusi pembiayaan bank syariah untuk sektor pertanian di Indonesia secara signifikan adalah variabel nilai tukar rupiah terhadap dolar dan variabel imbalan SBIS. Sedangkan variabel lain tidak signifikan secara statistik dalam mempengaruhi kontribusi pembiayaan bank syariah untuk sektor pertanian di Indonesia. Sementara dalam jangka panjang variabel yang mempengaruhi kontribusi pembiayaan bank syariah untuk sektor pertanian di Indonesia secara signifikan adalah jumlah dana pihak ketiga (DPK) dan Non Performing Financing (NPF) untuk sektor pertanian. sedangkan untuk variabel nilai tukar rupiah dan SBIS tidak berpengaruh signifikan pada jangka panjang. 


\section{Analisis Impulse Response Function (IRF)}

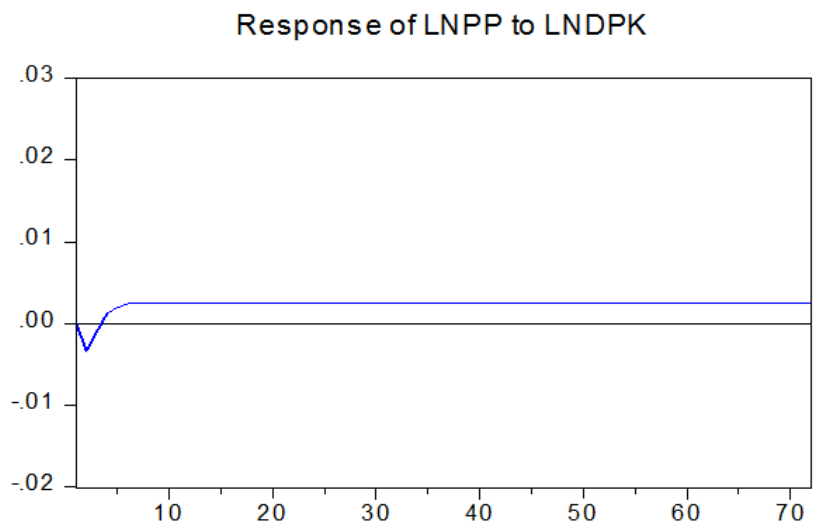

Gambar 5 Respon InPP terhadap InDPK

Respon yang diterima oleh pembiayaan untuk sektor pertanian di Indonesia dari guncangan yang terjadi pada jumlah DPK perbankan syariah (lnDPK) yang direspon negatif dalam jangka pendek dengan standar deviasi sebesar -0.003359 pada bulan ke-2. Namun respon yang diterima tidak berangsur negatif dalam jangka waktu yang lama, pada bulan ke-4 respon yang diterima oleh pembiayaan pertanian akibat penurunan jumlah DPK yang berhasil dihimpun perbankan syariah. Pada Gambar 5. pembiayaan untuk sektor pertanian mulai merespon positif pada bulan ke-4 dan mulai mencapai titik kestabilan pada bulan ke-7 dan benar-benar stabil pada bulan ke-19 dengan standar deviasi sebesar 0.002547 .

Hal ini sesuai dengan penelitian yang dilakukan oleh (Veratama, 2013) dan (Pratama, 2010) bahwa dana pihak ketiga berpengaruh signifikan terhadap pengguliran dana bank syariah. Pembiayaan yang diberikan oleh suatu perbankan sangat dipengaruhi oleh seberapa besar dana yang dapat disalurkan oleh suatu perbankan. Sebagai lembaga keuangan, dana merupakan suatu hal yang paling utama sehingga modal terbesar dari perbankan merupakan yang bersumber dari dana masyarakat melalui tabungan, giro, deposito dan produk penghimpunan dana lain yang ditawarkan oleh bank (Veratama, 2013). Namun hasil penelitian berbeda ditunjukkan oleh (Nandapipa, 2010) yang menunjukkan bahwa dana pihak ketiga berpengaruh tidak signifikan terhadap tingkat peengguliran dana bank syariah.

Response of LNPP to LNNPF

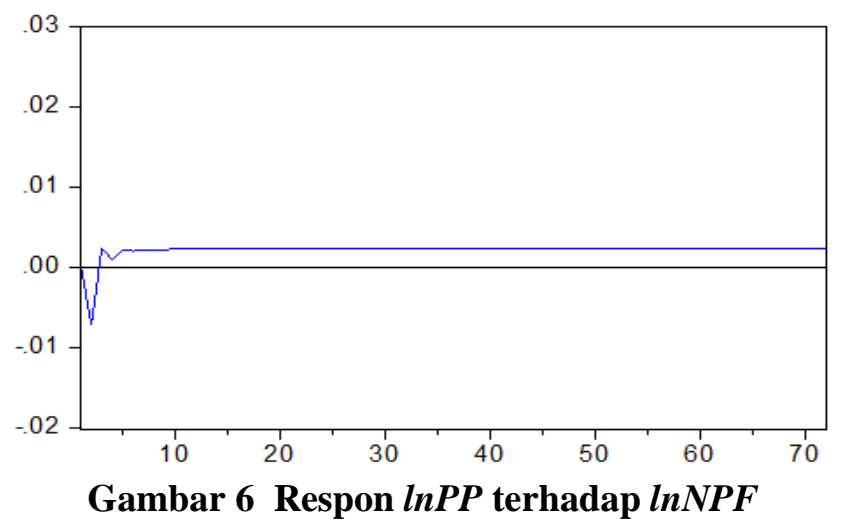

Pada variabel lnNPF guncangan yang terjadi terhadap pembiayaan sektor pertanian dalam jangka pendek memberikan respon negatif dengan standar deviasi sebesar -0.007082 pada bulan ke-2, namun selanjutnya direspon positif pada bulan ke-3 hingga mencapai nilai titik kestabilan pada bulan ke-10 dan mencapai benar-benar stabil pada bulan ke- 23 dengan standar deviasi sebesar 0.002360 hingga akhir periode. 
Sebagaimana yang terlihat pada Gambar diatas adalah respon guncangan yang terjadi pada variabel lnNPF terhadap pembiayaan untuk sektor pertanian di Indonesia yang direspon positif dalam jangka panjang oleh pembiayaan untuk sektor pertanian di Indonesia. Ini menunjukkan bahwa dalam jangka panjang kenaikan tingkat rasio kredit macet perbankan syariah mengakibatkan pada peningkatan pada jumlah dana yang disalurkan oleh perbankan syariah untuk sektor pertanian di Indonesia. Bank syariah tidak memberikan keketatan yang terlalu tinggi terhadap pengembalian dana pembiayaan yang dikeluarkan oleh perbankan syariah atas dana yang disalurkan dikarenakan tidak memberikan dampak yang baik bagi perbankan syariah. Bank syariah memberikan kelonggaran kepada masyarakat dalam melakukan pembayaran atas pembiayaan yang diterimanya agar masyarakat dapat lebih menerima pembiayaan bagi hasil yang disalurkan oleh perbankan syariah.

Hasil analisis NPF yang berpengaruh positif terhadap pembiayaan untuk sektor pertanian, hasil ini sejalan dengan penelitian yang dilakukan oleh (Nurjaya, 2011) dan (Firmansyah \& Nasrulloh, 2013) yang menyebutkan bahwa semakin ketat kebijakan pembiayaan yang dilakukan akan menyebabkan tingkat permintaan pembiayaan oleh masyarakat menurun.

\section{Respon $\ln P P$ terhadap $\ln E R$}

Pada Gambar dibawah menjelaskan respon pembiayaan untuk sektor pertanian di Indonesia terhadap guncangan yang terjadi pada nilai tukar rupiah (lnER) yang direspon secara positif oleh pembiayaan pertanian. dimulai dari bulan pertama, nilai terus mengalami peningkatan hingga mencapai titik kestabilan pada bulan ke-7 dan benar-benar stabil pada buan ke-19 dengan standar deviasi sebesar 0.021163 hingga akhir periode penelitian yang dilakukan. Respon positif yang diterima pembiayaan untuk sektor pertanian ini menunjukkan bahwa dalam jangka panjang ketika nilai rupiah terhadap dollar terjadi peningkatan atau terapresiasi, maka jumlah pembiayaan yang disalurkan oleh perbankan syariah untuk sektor pertanian dalam jangka panjang akan mengalami peningkatan.

Response of LNPP to LNER

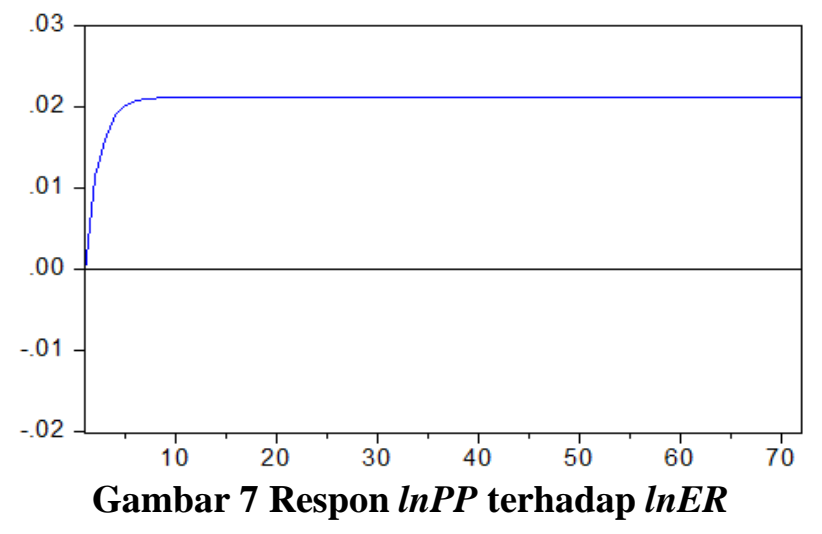

Hasil penelitian ini didukung oleh teori yang dikemukakan oleh (Mutamimah \& Chasanah, 2012) bahwasanya perubahan kurs mata uang juga akan sangat berpengaruh pada kelancaran usaha nasabah. Ketika nilai rupiah terapresiasi dalam arti lain harga-harga barang impor relatif murah, dengan demikian kecemasan perbankan dalam menyalurkan pembiayaan untuk sektor pertanian lebih kecil jika dibandingkan ketika nilai rupiah terdepresiasi. Begitupun sebaliknya jika nilai rupiah jatuh dibandingkan dengan valuta asing dan jika usaha tersebut dijalankan menggunakan bahan impor, maka akan memukul usaha nasabah dan dapat meningkatkan rasio pembiayaan bermasalah. Ketika NPF mengalami peningkatan akan mempengaruhi pada penurunan pembiayaan yang disalurkan oleh perbankan syariah. Hal ini juga didukung oleh penelitian yang dilakukan oleh (Sarjadyasari, 2010) yang menghasilkan nilai tukar rupiah berpengaruh positif dan signifikan terhadap pembiayaan.

\section{Respon $\ln P P$ terhadap $S B I S$}

Berdasarkan Gambar dibawah, dapat dilihat bahwa variabel pembiayaan (lnPP) dalam jangka panjang merespon negatif terhadap guncangan yang terjadi pada variabel SBIS dengan nilai terendah pada Jurnal Al-Muzara'ah Vol.4, No.1, 2016 
awal periode penelitian dengan standar deviasi sebesar -0.011612 dan mencapai nilai titik kestabilan pada bulan ke-4 dan benar-benar stabil pada bulan ke-19 dengan standar deviasi sebesar -0.015880 hingga akhir periode penelitian. Hal ini berarti ketika terjadi guncangan pada peningkatan rate imbalan SBIS maka dalam jangka panjang pembiayaan bank syariah untuk sektor pertanian akan mengalami penurunan.

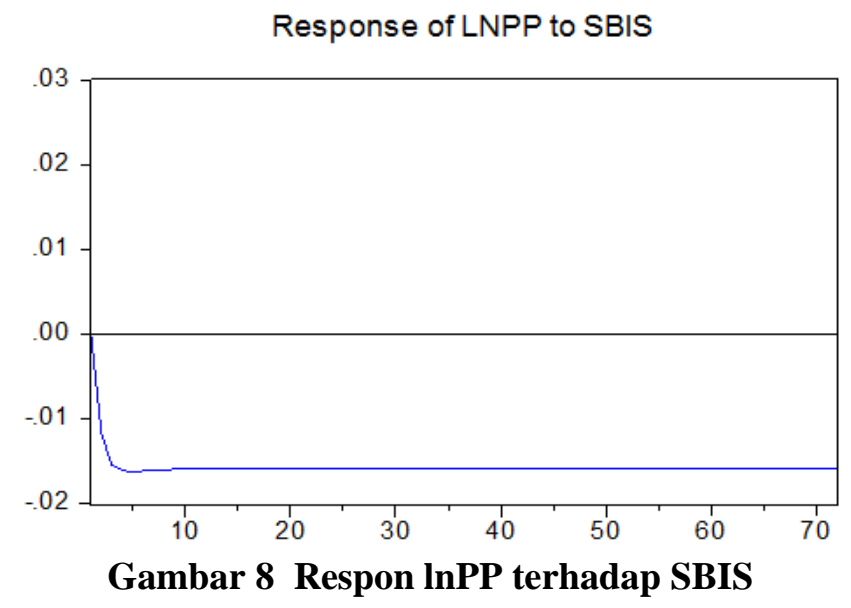

Analisis Forecast Error Variance Decomposition (FEVD)

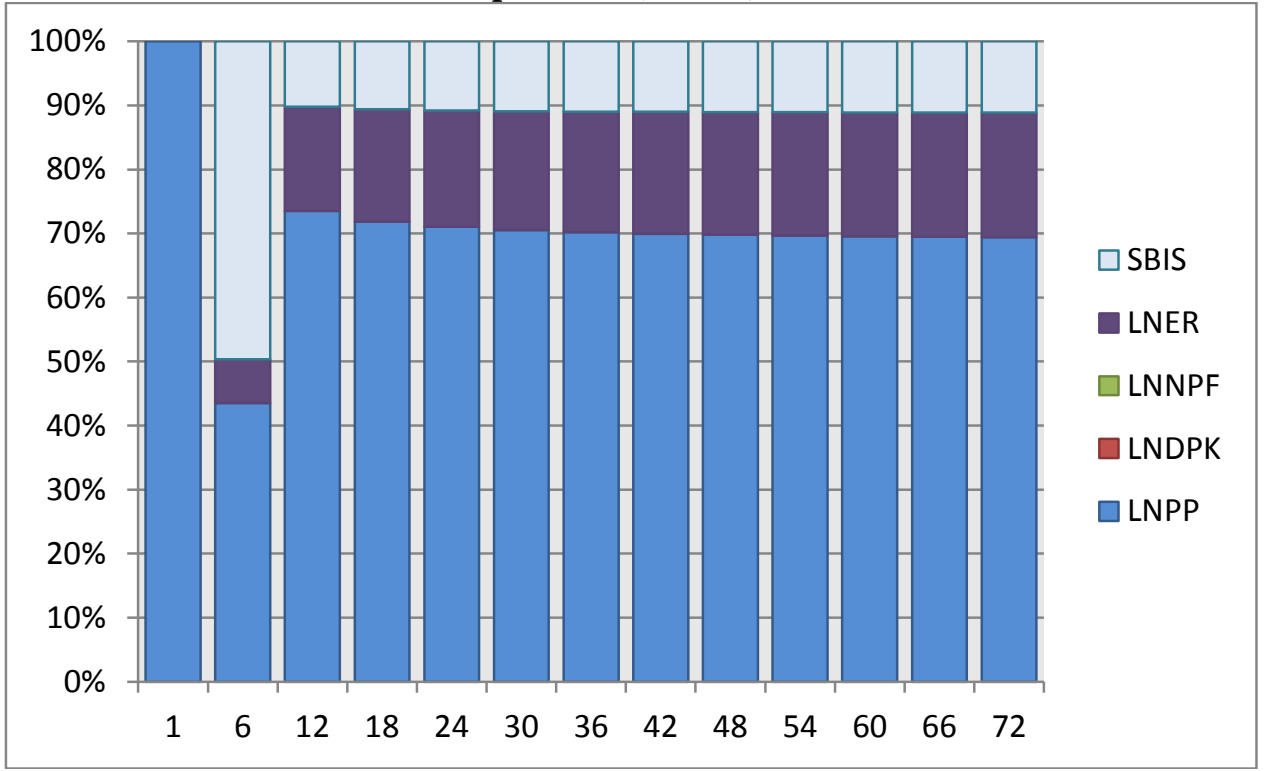

\section{Gambar 9 Hasil FEVD Keseluruhan Variabel}

Hasil Forecast Error Varians Decomposition (FEVD) untuk persamaan jumlah pembiayaan yang disalurkan oleh perbankan syariah untuk sektor pertanian menunjukkan bahwa pada bulan pertama, keragaman fluktuasi pembiayaan pertanian didominasi oleh pembiayaan pertanian itu sendiri sebesar 100 persen dan terus berlanjut hingga akhir periode dengan kontribusi yang semakin menurun.

Kontribusi mulai terlihat pada bulan kedua dimana permbiayaan untuk sektor pertanian memberikan kontribusi sebesar 92.39894 persen terhadap fluktuasinya sendiri. Pada periode tersebut variabel SBIS memberikan kontribusi sebesar 3.125062 persen, variabel lnER memberikan kontribusi sebesar 3.051982 persen, variabel lnNPF memberikan kontribusi sebesar 1.162502 persen dan variabel $\operatorname{lnDPK}$ memberikan kontribusi sebesar 0.261515 persen. 
Pada bulan kedua terlihat bahwasannya variabel yang memberikan kontribusi paling besar terhadap variabel pembiayaan untuk sektor pertanian adalah variabel pembiayaan untuk sektor pertanian (lnPP) itu sendiri dan diikuti oleh variabel SBIS dan lnER. Namun dari bulan ke bulan berikutnya lnER terus memberikan kontribusi yang besar terhadap pembiayaan untuk sektor pertanian di Indonesia, sehingga pada akhir periode variabel lnER memberikan kontribusi yang lebih besar terhadap pembiayaan untuk sektor pertanian di Indonesia jika dibandingkan dengan variabel SBIS. Diakhir periode variabel $\operatorname{lnDPK}$ memberikan kontribusi yang cukup lebih besar untuk pembiayaan sektor pertanian jika dibandingkan dengan variabel lnNPF yang cenderung terus menurun hingga akhir periode peramalan.

\section{Tabel 9 FEVD untuk Model InPP (akhir periode)}

\begin{tabular}{cc}
\hline Variabel & $\begin{array}{c}\text { Kontribusi Guncangan Variabel } \\
\text { Terhadap InPP (bulan ke-72) }\end{array}$ \\
\hline lnPP & 69.01541 \\
LnDPK & 0.280852 \\
LnNPF & 0.268449 \\
LnER & 19.36043 \\
SBIS & 11.07486 \\
\hline
\end{tabular}

Hasil FEVD diakhir periode keseluruhan variabel untuk persamaan kontribusi jumlah pembiayaan yang disalurkan oleh perbankan syariah terhadap sektor pertanian di Indonesia menunjukkan bahwa variabel $\operatorname{lnPP}$ itu sendiri dengan kontibusi sebesar 69\% variabel lnER memberikan kontribusi terbesar terhadap pembiayaan bank syariah utuk sektor pertanian di Indonesia sebesar 19,36\%, diikuti oleh variabel SBIS yang memiliki kontribusi sebesar 11,07\%, variabel lnDPK memberikan kontribusi sebesar $0,28 \%$ dan untuk variabel lnNPF memberikan kontribusi sebesar 0,27\%.

Dari hasil yang diterima, share terbesar untuk pembiayaan perbankan syariah sektor pertanian didominasi oleh indikator Makroekonomi dan Instrumen Moneter, artinya kontribusi dari internal perbankan tidak terlalu memiliki share yang besar dalam mempengaruhi penyaluran dana perbankan syariah untuk sektor pertanian di Indonesia. Hal ini menunjuukkan bahwasannya semakin kuat nilai rupiah terhadap dollar (apresiasi) maka akan meningkatkan pembiayaan perbankan syariah untuk sektor pertanian di Indonesia, dikarenakan sektor pertanian berperan sebagai salah satu penyumbang PDB negara dikarenakan mampu meningkatkan sektor riil.

Lain halnya dengan Imbalan SBIS yang ditawarkan oleh Bank Indonesia yang memiliki hubungan negatif dengan pembiayaan perbankan syariah. Ketika imbalan SBIS mengalami penurunan maka sktor perbankan lebih tertarik meletakkan dananya untuk pembiayaan perbankan. Dengan demikian pembiayaan untuk sektor pertanian mengalami peningkatan akibat kontribusi dari penurunan tingkat imbalan SBIS. Namun meski demikian, tidak berarti rate imbalan SBIS dalam jangka panjang terus mengalami penurunan, dikarenakan dengan rendahnya rate imbalan SBIS hal ini berarti uang yang beredar dimasyarakat juga mengalami peningkatan. Hal ini bukan merupakan kebijakan terbaik, alangkah baiknya ketika rate SBIS memiliki titik rendah untuk rate nya sehingga baik dari sisi moneter maupun riil tidak ada yang terabaikan.

\section{Kesimpulan}

Berdasarkan hasil penelitian yang telah dilaksanakan, maka diperoleh beberapa kesimpulan sebagai berikut:

a. Kontribusi pembiayaan bank syariah untuk sektor pertanian di Indonesia dapat dilihat melalui beberapa indikator ekonomi, diantaranya indikator perbankan syariah, moneter dan makroekonomi. Pada jangka pendek, variabel yang mempengaruhi kontribusi pembiayaan bank syariah untuk sektor pertanian di Indonesia secara signifikan adalah variabel nilai tukar 
rupiah terhadap dolar dan variabel imbalan SBIS. Sementara dalam jangka panjang variabel yang mempengaruhi kontribusi pembiayaan bank syariah untuk sektor pertanian di Indonesia secara signifikan adalah jumlah dana pihak ketiga (DPK) dan Non Performing Financing (NPF) untuk sektor pertanian.

b. Dari hasil IRF variabel perbankan syariah yang diteliti, didapatkan hasil sebagai berikut:

1) Guncangan yang terjadi pada variabel jumlah DPK perbankan syariah (lnDPK) direspon positif oleh pembiayaan pertanian untuk sektor pertanian di Indonesia. hal ini dapat diartikan bahwa ketika jumlah DPK mengalami peningkatan, pembiayaan pada perbankan syariah khususnya untuk sektor pertanian mengalami peningkatan sejalan dengan bertambahnya dana pembiayaan.

2) Guncangan yang terjadi pada variabel Non Performing Financing (lnNPF) direspon positif oleh pembiayaan pertanian. hal ini dapat diartikan bahwa ketika terjadi peningkatan rasio pembiayaan macet (lnNPF), akan mengurangi pembiayaan yang disalurkan oleh perbankan syariah khususnya untuk sektor pertanian.

c. Dari hasil IRF variabel makroekonomi dan moneter yang diteliti, di dapatkan hasil sebagai berikut:

1) Guncangan yang terjadi pada variabel nilai tukar rupiah (lnER) yang direspon secara positif oleh pembiayaan pertanian. Hal ini dapat diartikan bahwa ketika nilai tukar rupiah terdepsresiasi mampu memberikan respon yang positif terhadap pembiayaan perbankan syariah yang disalurkan untuk sektor pertanian.

2) Guncangan yang terjadi pada variabel SBIS dalam jangka panjang direspon negatif oleh pembiayaan pertanian (lnPP). Hal ini dapat diartikan bahwa ketika terjadi peningkatan pada imbalan SBIS, maka jumlah pembiayaan yang disalurkan oleh perbankan syariah untuk sektor pertanian akan berkurang. Hal ini sejalan dengan fungsi SBIS sebagai instrumen moneter untuk menyerap likuiditas berlebih dalam sistem ekonomi.

d. Hasil analisis Forecast Error Variance Decomposition (FEVD) menunjukkan bahwa variabel yang paling berpengaruh terhadap pembiayaan untuk sektor pertanian (lnPP) didominasi oleh pembiayaan pertanian itu sendiri sebesar 100 persen dan terus berlanjut hingga akhir periode dengan kontribusi yang semakin menurun. Pada bulan kedua, terjadi penurunan pada pengaruh lnPP itu sendiri sebesar 92\%, SBIS memberikan kontribusi sebesar $3,13 \%$, variabel $\operatorname{lnER}$ memberikan kontribusi sebesar 3,05\%, variabel lnDPK memberikan kontribusi sebesar $0,26 \%$ dan variabel lnER memberikan kontribusi sebesar 1,16\%. Diakhir periode penelitian yang ditentukan, kontribusi atau share yang diberikan oleh masing-masing variabel baik dari indikator makroekonomi, moneter maupun indikator perbankan syariah terhadap pembiayaan yang disalurkan oleh perbankan syariah untuk sektor perbankan yaitu SBIS sebesar 11,07\%, variabel $\operatorname{lnER}$ sebesar $19,36 \%$, variabel $\operatorname{lnDPK}$ sebesar $0,28 \%$ dan variabel $\operatorname{lnNPF}$ sebesar $0,27 \%$.

\section{Daftar Pusaka}

Abdussalam. (2009). Pengaruh Variabel Makro dan Mikroekonomi Terhadap Pertumbuhan Perbankan Syariah Indonesia. Skripsi (tidak dipublikasikan), Bogor. STEI Tazkia.

Antonov, T. S. (T,th). Akad Mudharabah. Makalah Akuntansi Syariah .

Arsana, I. (2004). VAR (Vector Auto Regressive). Jakarta: Laboraturium Komuptasi Ilmu Ekonomi FEUI.

Ascarya. (2009). Aplikasi Vector Autoregression dan Vector Error Correction Model Menggunakan EVIEWS 4.1.

Astuti, N. W. (2009). Pengaruh Dana Pihak Ketiga, Profit dan Non Performing Financing Terhadap Pembiayaan Bagi Hasil Pada Bank Umum Syariah dan Unit Usaha Syariah Periode 20052008. Skripsi .

Beik, I. S., \& Aprianti, W. N. (2013). Analisis Faktor-faktor yang Mempengaruhi Pembiayaan Bank Syariah untuk Sektor Pertanian di Indonesia. Jurnal Agro Ekonomi. Volume 31. 1, Mei 2013: 19-36. 
Enders, W. (2004). Applied Econometric Time Series. 2nd Edition. New York: John Wiley and Sons, Inc.

Faisal, R. F. (2013). Peran Pembiayaan Bank Syariah Terhadap Pengembangan Sektor Riil (Studi Kasus pada Bank Jatim Syariah Cabang Surabaya). Artikel Jurnal , 9.

Firmansyah. (2009). Efektivitas Pola Pembiayaan Syariah Dalam Pengembangan Sub-Sektor Hortikultura, Efektivitas Model Pembiayaan Syariah dalam Mengembangkan Sektor Pertanian. Jakarta: LIPI Press, anggota Ikapi.

Firmansyah, I., \& Nasrulloh, A. A. (2013). Analisis Pembiayaan Bagi Hasil Pada Bank Umum Syariah di Indonesia. Jurnal Ekonomi dan Bisnis Islami. Volume III Nomor 1, Juni 2013 , 6270.

Gujarati, D. N., \& Porter, C. D. (2009). Basic Econometrics, International Edition. McGrawHill Press.

Hastuti, E., \& Supadi. (T,th). Aksessibilitas Masyarakat Terhadap Kelembagaan Pembiayaan Pertanian di Pedesaan.

Mançka, D. A. (2012). Lending Problems of Agriculture and Agro-Industry in Albania. Ontario International Development Agency. OIDA ISSN 1923-6654. International Journal Of Sustainable Development 03:04 .

Maula, K. H. (2008). Pengaruh Simpanan Dana Pihak Ketiga, Modal Sendiri, Margin Keuntungan dan NPF (Non Performing Financing) Terhadap Pembiayaan Murabahah Pada Bank Syariah Mandiri. Skripsi .

Mutamimah, \& Chasanah, S. N. (2012). Analisis Eksternal dan Internal Dalam Menentukan Non Performing Financing Bank Umum Syariah di Indonesia. Jurnal Bisnis dan Ekonomi (JBE), Maret 2012. Vol. 19, No. 1; ISSN: 1412-3126, 4.

N.P, W. A., \& Muharam, H. (2011). Analisis Pengaruh Dana Pihak Ketiga (DPK), Capital Adequacy Ratio (CAR), Non Performing Ratio (NPF) dan Return On Asset (ROA) Terhadap Pembiayaan Pada Perbankan Syariah (Studi Kasus Pada Bank Muamalat Indonesia Periode 2001-2011.

Nandapipa, S. (2010). Analisis Pengaruh CAR, NPL, Inflasi, Pertumbuhan DPK, dan Exchange Rate Terhadap LDR (Studi Kasus pada Bank Umum di Indonesia Periode 2004-2008). Universitas Dipenogoro, Semarang .

Nurjaya, E. (2011). Analisis Pengaruh Inflasi, Sertifikat Bank Indoesia Syariah (SBIS), Non Performing Financing (NPF) dan Dana Pihak Ketiga (DPK) Terhadap Pembiayaan Murabahah Pada Bank Syariah di Indonesia (Periode Januari 2007 - Maret 2011). Skripsi .

Nurmanaf, A. (2007). Lembaga Informal Pembiayaan Mikro Lebih Dekat Dengan Petani. Pusat Analisis Sosial Ekonomi dan Kebijakan Pertanian. Analisis Kebijakan Pertanian Volume 5 No. 2, Juni 2007, 99-109.

Nurmanaf, A., Hastuti, E., Ashari, Friyatno, S., \& Wiryono, B. (2006). Analisis Sistem Pembiayaan Mikro Dalam Mendukung Usaha Pertanian di Pedesaan. Laporan Penelitian. Pusat Analisis Sosial Ekonomi dan Kebijakan Pertanian. Departemen Pertanian .

Pasaribu, S., Sayaka, B., Sejati, W. K., Setiyanto, A., Hestina, J., \& Situmorang, J. (2007). Analisis Kebijakan Pembiayaan Sektor Petanian. Pusat Analisis Sosial Ekonomi dan Kebijakan Pertanian (hal. 8-10, 13-14, 17-21). Jakarta: http://pse.litbang.pertanian.go.id.

Pertanian, B. U. (2015, Agustus 21). Tahun 2014/2015, Puso Akibat OPT Seluas 476 Ha (0,01 Persen). Dipetik Agustus 23, 2015, dari Kementrian Pertanian RI: http://www.pertanian.go.id

Pratama, B. A. (2010). Analisis Faktor-faktor Yang Mempengaruhi Kebijakan Penyaluran Kredit Perbankan (Studi pada Bank Umum di Indonesia Periode Tahun 2005-2009). Tesis, Program Studi Magister Manajemen Program Pascasarjana Universitas Dipenogoro .

Rimadhani, M., \& Erza, O. (2011). Analisis Variabel-variabel Yang Mempengaruhi Pembiayaan Murabahah Pada Bank Syariah Mandiri Periode 2008.01 - 2011.12. Media Ekonomi Vol. 19, No. 1, April 2011 .

Sarjadyasari, A. (2010). Analisis Pengaruh Modal Inti, Dana Pihak Ketiga (DPK), Suku Bunga SBI, Nilai Tukar Rupiah (Kurs) dan Inflasi Terhadap Pembiayaan yang disalurkan (Studi Kasus Bank Muamalat Indonesia). Skripsi . 
Thoha, M., \& Saptia, Y. (2009). Efektivitas Model Pembiayaan Syariah Dalam Mengembangkan Sektor Pertanian. Jakarta: LIPI Press, anggota Ikapi.

Veratama, Y. (2013). Pengaruh Kurs, Inflasi, DPK, SWBI, dan Pendapatan Bank Terhadap Tingkat Perguliran Dana Bank Syariah (Studi Pada Bank Umum Devisa Syariah Periode 2011-2013). 13-14.

Wangsawidjaja Z, A. (2012). Pembiayaan Bank Syariah. Jakarta: PT. Gramedia Pustaka Utama.

Yasin, A. (2015). Karakteristik dan Best-practice Pembiayaan Sektor Pertanian, Program Pembiayaan Pertanian. Jakarta Timur: PT. Nagakusuma Media Kreatif.

www.bps.go.id

www.bi.go.id 